\title{
Environmental Genomics and Biodiversity of Macro- and Microbenthic Communities in the Red Sea Coast of Jeddah City
}

\author{
SAMAH SULAIMAN ${ }^{*}$, BAESHEN, M. N. ${ }^{2}$, ALI AL-KELDI ${ }^{3}$, HAYAM S. ABDELKADER ${ }^{4}$ \\ Department of Biology, College of Science, University of Jeddah, Jeddah, Saudi Arabia. \\ *Corresponding Authors: SAMAH SULAIMAN, Department of Biology, College of Science, University \\ of Jeddah, Jeddah, Saudi Arabia.
}

\section{BACKGROUND}

Kingdom of Saud Arabia covers about $80 \%$ of Arabian Peninsula; it occupies an area of about 2,250,000 square kilometers (EI Raey, 2010). The country has an arid climate with an average annual rainfall of $70.5 \mathrm{~mm}$ along the broad coastal Tihamah plains of Red Sea (Hariri, 2012). The largest section of Saudi Arabian's Red Sea coastline (Figure 1) extends about $1800 \mathrm{~km}$ to the west; from Jordan to Yemen (Khalil, 2017). The Red Sea is a young environment that began to form after the northeast African continental crust began to divide and drift eastward (Berumen et al, 2019). The present dimensions and structure of the Red Sea are the result of a combination of geological and climatic processes, including the spreading between the African and Arabian plates, associated volcanism in the midTertiary, and eustatic sea-level fluctuations (Di Battista et al., 2016). Tertiary faulting in the area between Africa and Arabia led to the formation of the Red Sea rift. Red Sea Red Sea Mountains are characterized by a steep western edge and a gently east-dipping Arabian Shield. The landmass lies between the mid-latitudes; in a typically arid area dependent on winter rains in the north and monsoon winds in the south.

The Red Sea lies as an elongated, north-south oriented oceanic basin extending from $30^{\circ} \mathrm{N}$ to $12^{\circ} 40^{\prime} \mathrm{N}$ between Asia and Africa (Rasul and Stewart, 2015). It is surrounded by desert landscapes where rivers are scarce, with a modest area $(438,000 \mathrm{~km} 2)$ (Alsaffar, 2018).

Red Sea countries include Egypt, Sudan, Eritrea, and Djibouti on the west coast, with Saudi Arabia and Yemen on the east coast. The Red Sea has many fascinating geomorphological characteristics, such as its extreme depths, particularly along its long axis, and the unusually high elevations along much of its rough shoulder. The oceanic spreading centers in the Red Sea are profoundly bound to the depths (Rasul and Stewart, 2015). its depths range from shallow along the coral coasts $(50 \mathrm{~m})$ to deep in the shelf/offshore areas (500-1000 m) or in the trench itself (at least $1000 \mathrm{~m})(1000 \mathrm{~m})$.

Marine environments are broadly divided into two aquatic environments: a pelagic and a near-bottom or benthic. Within the pelagic environment, water is divided into the neritic province, which includes water above the continental shelf and is characterized by high nutrient content resulting from solutes in river runoff, and the oceanic province, which includes all open water beyond the continental shelf (Dupuy et al., 2015).

In addition, the benthic environment is divided into a number of unique ecological zones based on depth, seafloor topography and vertical gradients of physical parameters; in particular, the balance between stabilizing and destabilizing biotic effects (Schratzbergera and Ingels, 2020). These are: a) the supralittoral (above the high-water mark but not submerged), b) the intertidal or littoral zone, c) offshore water, and d) the sublittoral or ambient zone. The sediments of the continental shelf that affect marine organisms generally originate from the land (Joydas and Borja, 2019). The intertidal soft sediment habitat is classified as one of the most productive ecosystems on earth; mainly due to the primary production of highly diverse collections of benthic diatoms (Dupuy et al., 2015).

Haeckel coined the term benthos in 1891, which is derived from the Greek verb $\beta \alpha o s$, noun $\beta \varepsilon \dot{v} \theta 0 \varsigma$ (váthos, rank, degree), related to bathos, depth, bathys, deep, high, meaning depth of the sea (Zaleha, 
2009). Benthic or benthic zones represent a community of living organisms on, in, or near the seafloor, rivers, lakes, or stream bottoms. They include microorganisms that live in and on sediments that inhabit rocky substrates and make up the biodiversity.

This populations of bacteria, archaea, eukaryotic microbes, and viruses represent nearly abysmal levels of aquatic biodiversity (Thompson et al., 2017). Studying the mechanisms that control the metabolism of human organisms, as well as how those processes interact with the biotic and abiotic environment, would present a challenging issue (Graham et al., 2016).

Computational capacity and new sophisticated molecular methods are reducing the expense of wholegenome DNA sequencing and are spurring marine microbial research (Davenport and Tümmler 2013). e.g. Next-generation whole-genome sequencing (WMGS) has allowed more in-depth analyses to elucidate a greater number of microbial species taxa discovered in environmental samples (Meyer et al., 2019). High-throughput amplicon-dependent sequencing technologies based on interspecific variations in individual marker genes (16S ribosomal RNA; 16S rRNA) are commonly employed for analyzing benthic microecological diversity (Props et al., 2016).

This paper aims to review and discuss 1) how these benthic communities are crucial for the functioning of coastal ecosystems, which are subject to increasing anthropogenic pressures and are considered one of the most affected ecosystems worldwide. 2) The extreme threat to biogenic habitats, such as seagrasses, macroalgae and biogenic reefs, which are acutely threatened by environmental change. 3 ) The implementation of environmental genomics to study the taxonomic identification and functional metagenomics of marine benthic metazoans and micrometazoans.

\section{The UniQue Characteristics of Red SEa Ecosystem}

The Red Sea represents one of the most extreme environments in the world (Dreano et al., 2016). Remotely measured SST ranges from an average of $31.3 \pm 1.1^{\circ} \mathrm{C}$ in the south Red Sea to $26 \pm 1^{\circ} \mathrm{C}$ in the far north (Monroe et al., 2018). This salty marine ecosystem has a salinity about 39\% (about 4\% higher) than the global ocean average. In the Red Sea, $40 \%$ of the seafloor is less than $100 \mathrm{~m}$ deep and $25 \%$ is lower than $50 \mathrm{~m}$ with a broad variety of seasonal water temperature regimes ranging from 18 to $32{ }^{\circ} \mathrm{C}$ (Ellis et al., 2017). Surface ocean water temperatures are $21-25^{\circ} \mathrm{C}$ year-round (Hariri, 2012) suggests that this closed and semi-isolated habitat, the Red Sea, works differently from other marine ecosystems (Joydas et al., 2019). These extreme conditions, along with an oligotrophic nature indicated by the low rate of primary production and low concentrations of nutrients, suggest that this closed and semiisolated ecosystem; Red Sea, functions differently from other marine areas (Joydas et al.,2019). The extreme depths along the Red Sea basin axis, which are closely related to the development of oceanic spreading centers, and the high elevations along most of the rifted shoulder are the most notable geomorphological features (Rasul and Stewart, 2015). Seasonal climatic cycles and local wind systems of the Red Sea is illustrated in Figure 2. It ecologically represents one of the most important repositories of highly biodiverse marine hotspots and a highly endemic region in the cosmos (Fine et al., 2019).

The exclusive fauna of the Red Sea along with a tumultuous geological history and unusual environmental conditions; including minimal freshwater inflows, high evaporation rates and latitudinal gradients in environmental variables (temperature, salinity and nutrients) and relative isolation, result in an enormous range of ecosystems, biodiversity and endemism; extreme among reef fish and reefassociated organisms (DiBattista et al., 2016). The distinct physico-chemical gradient along the northsouth axis of Red Sea has an intense influence on biology (Dreano et al., 2016). The southern shores of Red Sea can be recognized by narrow $(18 \mathrm{~km})$ and shallow $(137 \mathrm{~m})$ shores, turbid waters, and biological separation from the rest of the basin; by the presence of extensive mangrove habitats, less developed coral reefs, and increased presence of seagrasses and macroalgae. Due to its proximity to the strait Bab El-Mandeb, which connects it to Indian Ocean, the southern Red Sea water is less salty and more nutrient rich (Nanninga et al., 2014) and represents the most productive area; with enormous phytoplankton blooms (Dreano et al., 2016). Nowadays, the expansion of aquaculture in Red Sea to meet food needs and provide healthy diet can be harmful to the environment, considering the original oligotrophic status of the system by altering the biogeochemistry of the water and sediment (MartinezPorchas and Martinez-Cordova, 2012); as frequent and continuous nutrient inputs to the marine environment can lead to oxygen depletion, hydrogen sulfide accumulation, and wastewater discharges 

of Jeddah City

(onshore plants) with a large amount of organic material (carbon, nitrogen, and phosphorus) entering the coastal zone (Zhang et al., 2020), resulting in changing benthic community patterns in terms of species numbers, total abundance, individual fitness and biomass (Alsaffar et al., 2019). Despite its unique characteristics, the Red Sea area is relatively inaccessible due to permit regulations (Joydas et al., 2019). Consequently, it remains a poorly studied system (Berumen et al., 2013). There is a real lack of understanding of the general ecology of the Red Sea region and the increasing anthropogenic influences affecting it (Ellis et al., 2017). Studies have mainly focused on mineralogy, paleontology, geochemistry, and heavy metal concentrations. Research on nearshore soft sediment benthic communities is mainly limited to a $6 \mathrm{~km}$ stretch of coastline in the far north of Red Sea; near Al-Aqaba Gulf (Alsaffar, 2018).

Few studies provided initial records of soft sediment macrobenthos abundance in this region and also suggested high benthic species diversity in the soft sediment (Ellis et al., 2017). Published studies on benthos from the Red Sea are few and most of them focused on deeper waters (Joydas et al., 2018). Studies on benthos from the shallow environment are very limited (Alsaffar et al.,2019). Few studies are conducted, mainly in Farasan Islands; south of Red Sea, focusing on foraminifera and the relatively deeper and open areas on the inner and outer shelves. Therefore, shallow water macrobenthic communities $(1 \mathrm{~m})$ in the vicinity of Red Sea, specifically associated with vegetative habitats, are still largely unknown (Abrogueñ et al., 2020). Also, most studies are conducted along a $6 \mathrm{~km}$ stretch of the far northern shoreline of Red Sea; near Al-Aqaba Gul. Soft sediment benthos studies are very limited; therefore, this study was conducted to fill the knowledge gap on benthos and provide baseline data for the southern part of the coast Red Sea. Subsequent studies have been hampered by a lack of geographic range information (Berumen et al., 2013), but recent academic investments by several countries bordering the Red Sea have improved accessibility and integration of molecular and morphological research (Fine et al., 2019).
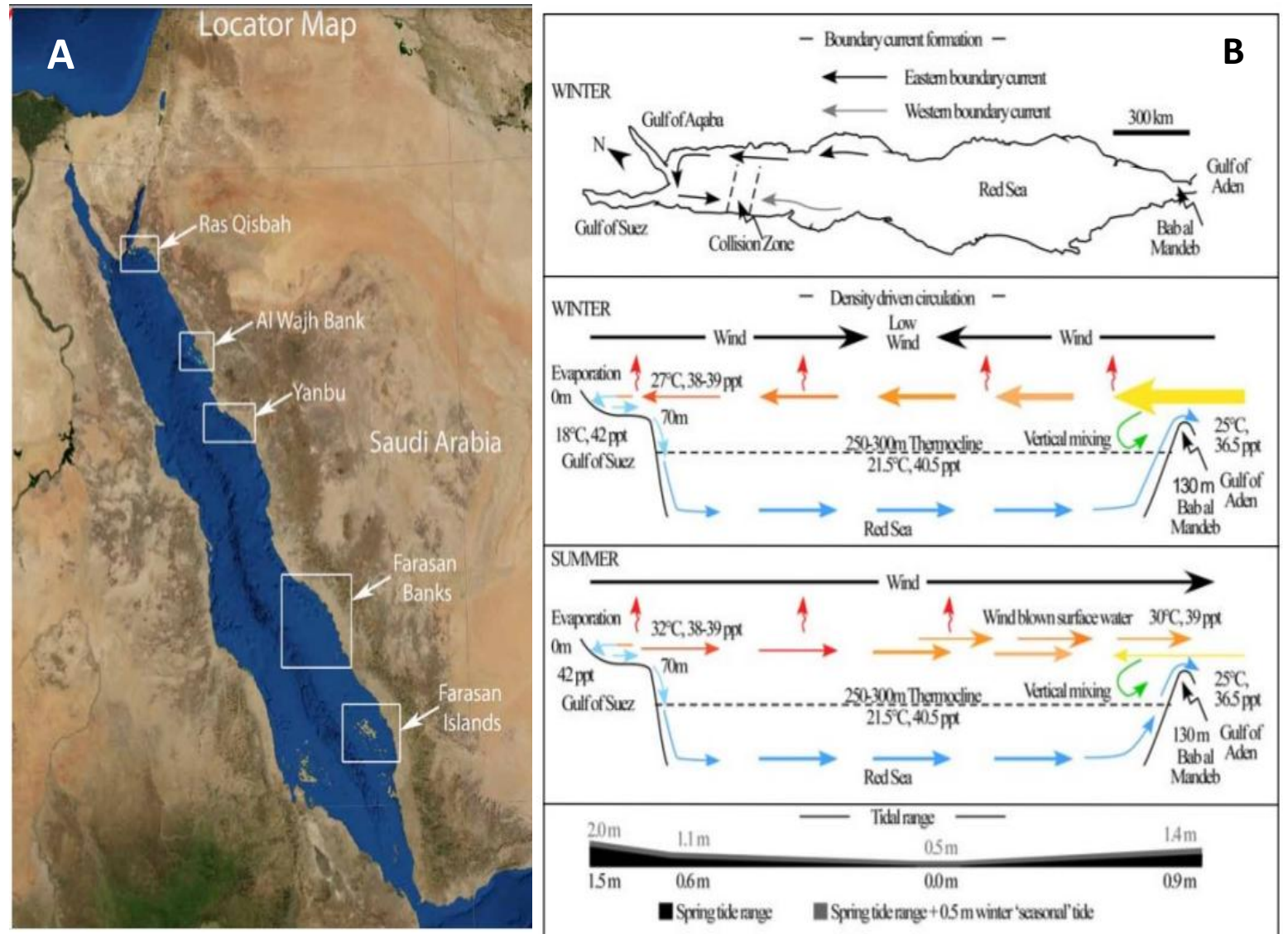

Figure1. A). Site map of Red Sea. B) Schematic representation of the predominant flow direction of water through the boundary current (top), effects of wind and evaporation on water circulation in winter (top center) and in summer (bottom center). The bottom figure shows a cross-section of the basin Red Sea, illustrating the tidal range during spring tides in the summer months and the seasonal rise of spring tides in winter. (Figure adapted from Atlas of Saudi Arabian Red Sea Marine Habitats. (Bruckner et al., 2012) 


\section{Distribution OF BENTHIC ECOSYSTEM}

The benthic ecosystem is a complex of living organisms, their physical environment, and all their interactions at the bottom of a body of water. The benthic community is composed of different species including plants, animals and bacteria that come from different parts of the food chain (Joydas and Borja, 2019). The benthos may be classified on various bases, as follows:

1) By substrate; the benthos includes the infauna and the epifauna. Infauna are organisms that live in the sediment, such as worms and bivalves, while epifauna are organisms that are attached to either the bottom or the substrate and make up $80 \%$ of benthic organisms. Examples of epifauna include sponges, oysters, clams, and starfish. In a stable and productive ecosystem, both epifauna and infaunal benthic organisms are present to circulate nutrients and contribute to a dynamic, complex food web (Henseler et al., 2019).

2) By species; benthos includes: a) zoobenthos; a term applied to all consumers (benthic protozoans and metazoans), including animals (members of animal origin) (Joydas and Borja, 2019); such as starfish, oysters, mussels, and b) phytobenthos (of plant origin); which are mainly various algae and aquatic plants, benthic diatoms, macroalgae and sea grasses (SFS, 2013).

3) Depending on the location, benthos is classified into endobenthos, epi- and hyperbenthos (Joydas and Borja, 2019). Endobenthos are organisms adapted to live in sediments by creating underground tunnels where they live buried or burrow into the bottom of sediments, often in the oxygen-rich upper layer; such as seahorses and sand dollars (Zeppilli et al., 2018). Epibenthos inhabits the top of sediments and spends its life on the bottom, on rocks or shells; such as sponges, sea cucumber and sea snail. Hyperbenthos; organisms only live suspended above sediments, have the ability to swim and live near the bottom but are not attached to it; such as the stockfish (Wikipedia, 2020).

4) Based on mobility, benthic organisms are classified as sessile or attached, sedentary, and vagrant. Sessile benthic organisms are organisms without mobility that are firmly attached to the substrate or bottom of the water body and rely on currents or other mechanisms to bring food to them. Typical examples include benthic algae (sea-weeds) and seagrasses as well as corals, attached barnacles and oysters (Naskar, 2019). Sedentarians; these are all slow-moving animals such as snails and slugs, while vagrants; which are animals that move and travel either very fast or slowly (Teixeira, 2010); such as land crabs and stingrays. Only animals fall under this category. Many benthic species, whether sessile or motile, produce motile planktonic larvae. This is important, especially for the ecology of sessile benthos. It allows these species to colonize new areas and reduce population densities in regions that may be overcrowded. Sessile benthic species wait for their food to come to them, while mobile species move in search of prey (Shaltout, 2019).

5) According to size, the benthos comprises three classes; micro-, macro- and meiofauna. The microbenthos is expressed by the benthic microscopic species; less than about $0.1 \mathrm{~mm}$ in size, that live in, on, or near the bottom of the water body and consist largely of bacteria and protozoa, especially ciliates, flagellates, amoebae, and diatoms (Giere, 2009). Marine microorganisms, both prokaryotic and eukaryotic, are key components of planktonic ecosystems in all marine biomes (Caron et al., 2012). In marine environments, microfauna rapidly colonizes and form biofilms on biotic and abiotic surfaces. Marine microbial communities are commonly divided into free-living and particle-associated (Dang and Lovell, 2016). Detrital aggregates of particle-associated communities are hotspots of microbial diversity that are fundamentally different from free-living communities. Particles are also habitats of increased enzyme activity (Kellogg and Deming, 2014), which contributes to the rapid turnover of particulate organic matter (POM). Particle-associated microorganisms play an important role in biogeochemical processes (Pinnell and Turner, 2019). Unicellular eukaryotes are present in nearly all environments, including soils, oceans, and plant- and animal-associated microbiomes (microbes in a discrete habitat, also called omics) (Grossart et al., 2020). They exist in symbiosis with plants and animals and interact with other microbes (Karin et al., 2020). Marine microbial eukaryotes are fundamental components of all marine ecosystems. As grazers and parasites, they help export carbon to the deep ocean and remineralize nutrients (Edgcomb, 2016; Obiol et al., 2020). They contribute significantly to carbon and nitrogen cycling through fixation of $\mathrm{CO}_{2}$, decomposition of organic matter (OM) and denitrification (Woehle et al., 2018); and are a source of chemical bioactive compounds (Karin et al., 2020). These processes vary seasonally and influence global biogeochemical cycles 
(Polinski et al., 2019). Microbial communities are essential components of aquatic ecosystems through their contribution to food web dynamics and biogeochemical processes (Grossart et al., 2020). At each low tide, intertidal surfaces are rapidly covered by mats of microalgae (microphytobenthos; MPB). Diatoms migrate through the fine sediments in response to tides and daily insolation cycles to find optimal light conditions for their growth. The MPB forms a complex biofilm in association with prokaryotic communities consisting mainly of bacteria on the sediment surface. These prokaryotes play a fundamental role by degrading and remineralizing nutrients. The components of the biofilm (MPB and prokaryotes) are important ecosystem engineers in food webs (Savelli et al., 2018). In addition, diatoms are important trophic sources for many benthic organisms (meio- and macrofauna) and prokaryotes provide a complementary food source for meio- and macrofauna (Dupuy et al., 2015).

However, the analysis of marine microbial eukaryotes and zooplankton is difficult because they are represented by hundreds of thousands of different taxa belonging to almost all phylogenetic groups of eukaryotes and the vast majority of them cannot be cultured because they are represented by hundreds of thousands of different taxa belonging to almost all phylogenetic groups of eukaryotes and the vast majority of them cannot be cultured. Their highly variable genome sizes, spanning at least four orders of magnitude, and the prevalence of non-coding sequences are additional challenges that have complicated their genomic study. For this reason, the study of marine microbial eukaryotes and zooplankton is mainly limited to the morphological description of diversity and taxonomic and biogeographic traits using single barcode genes (Carradec et al., 2018).

Macrobenthic organisms are comparatively large benthic organisms visible to the naked eye that are larger than $1 \mathrm{~mm}$ and live on or near the bottom of the water, such as sea grasses, echinoderms, sponges, polychaetes, bivalves, sea anemones, corals, sea squirts, turbellaria, and larger crustaceans, such as crabs, lobsters, and kumaceans (Li et al., 2016). Along the coast of Saudi Arabian (Red Sea), 199 macrofaunal species have been recorded, of which polychaetes, crustaceans and mollusks are the most important taxa (Joydas et al., 2019). Some macrobenthic organisms, called deposit feeders, feed on organic material in the sediments; such as holothurians, echinoids and gastropods. Others, suspension feeders, feed on the plankton above; such as bivalves, ophiuroids and crinoids, while a third class called predators consume other fauna in the benthic assemblage; such as starfish and gastropods (Kingsford, 2018). Benthic deposit feeders spend a considerable amount of their activity in the bidirectional exchange of water between pelagic and benthic ecosystems; through active pumping, through complex interconnected ditch systems (Moyo et al., 2017). This irrigation oxygenates the water in the burrows and removes fecal matter, anoxic/hypoxic water and potentially toxic compounds such as $\mathrm{H}_{2} \mathrm{~S}$. This exchange causes suspended particles, including phytoplankton and others OM, to adsorb onto the walls of the caves and adjacent sediments (Pillay, 2019). The addition of mucus to cave linings increases the adsorption properties and stability of particles. Additionally, microbial biofilms lining the cave walls increase the adhesion of particles; through exopolymer exudation (Venter et al., 2020).

In this regard, macrobenthic fauna play an important role in the marine ecosystem, especially in the sandy coastal systems. They serve as the main food source for most marine organisms during their different life stages, from juveniles to adults. They are also subject to the complex food web and nutrient recycling in the marine ecosystem (Holzhauer et al., 2020). Most macrobenthic processes oxygenate the underlying sediments and degrade the OM before

bacterial demineralization. Many of them, especially bivalves, are considered a food source for humans, in addition to their use for ornamental and recreational purposes (Tagliapietra and Sigovini, 2010). Four processes can influence the diversity and abundance of macrobenthic communities: selection, drift, speciation and dispersal. Selection plays a fundamental role in determining macrobenthic structure (Armenteros et al., 2018). The assemblage of these organisms may be driven by ecological gradients defined by one or more environmental factors, such as pollutant concentration, salinity, water depth, etc. However, abiotic heterogeneity and biotic interactions within habitats also play a major role (Kraft et al., 2015). Habitat selection is the result of a complex set of physical, chemical, and biological factors that together determine macrobenthic community structure (Ferraro, 2013). Benthic species composition in shallow coastal areas is closely related to habitat characteristics (sedimentology and morphology) and physical drivers in the system (wave dynamics, tidal dynamics, and sediment dynamics). This relationship is scale dependent (Holzhauer et al., 2018). The determinants of spatial diversity patterns are scale-dependent and dispersal and environmental selection are increasingly 
important at regional scales, while species interactions play a more important role at local scales (Biswas et al., 2016). Most interestingly, anthropogenic disturbance strongly influences aquatic macroinvertebrate species richness. The benthos, especially the macro, is important to the ecosystem as it consists of a wide variety of species assemblages with a wide range of tolerances and responses to natural and anthropogenic stresses, such as organic and inorganic pollutants (Mosbahi et al., 2019). Macrobenthos tend to remain in their original habitats, with a great capacity for acclimation (Moreyra and Padovesi-Fonseca, 2015). They are mainly sedentary with limited mobility. This prevents them from avoiding deteriorations in local conditions and gives them a long-life span; they provide an integrated response to environmental changes over time (Alsaffar, 2018) and consequently can tolerate changes in water quality and high pollution loads. Under pollution conditions, community structure may simplify in favor of tolerant species, but the abundance of a given species may increase even though diversity and species richness decrease (Armenteros et al., 2018); therefore, they are used as good indicators of local marine health conditions, such as water quality (Ncube et al., 2018).

Water quality can be assessed by evaluating the diversity and functional groups of indicator species of the benthic macrofaunal community. Benthic macroinvertebrates are a valuable component of ecosystems due to their direct dependence on sediment and their relatively rapid response to both anthropogenic and natural stresses (Teixeira, 2010) and are often used as bioindicators in ecological assessments (Pinto et al., 2009). Therefore, macrobenthos is a good bioindicator for biological monitoring programs of environmental changes in any aquatic ecosystem (Belal et al., 2016). Moreover, macroinvertebrates vary in their sensitivity to organic pollution and environmental impacts; both from point and non-point pollution sources, hence their relative abundances are used to make inferences about pollution loads (Patrick et al., 2015). In addition, macroinvertebrates play a key role in marine ecosystems by linking decomposer and producer food chains to top predators. They inhabit the entire length of the aquarium with a large number of species, limited mobility and relatively longlife span (Ghasemi and Kamali, 2014).

They serve as the primary food source for many commercially and recreationally important fish species. When monitored along with relevant chemical/physical parameters, benthic communities can be used to identify sources of impairment (Ghasemi and Kamali, 2014). They are holistic indicators of overall water quality. There are several advantages in using benthic macroinvertebrates in bioassays as they constitute a significant proportion of biodiversity and are critical to ecosystem function (Wen et al., 2020).

The use of benthic communities as bioindicators has great advantages; as they are global pollution/disturbance indicators with a real impact on the biota at the species community level and with elements that can be easily processed. In addition, macrobenthic organisms are useful and appropriate indicators due to other special characteristics; including: (i) they live in bottom sediment where they are exposed to pollutants and oxygen stress, (ii) they are sedentary and reflect the quality of their immediate environment, (iii) they are mostly long-lived and can therefore conjugate changes in water and sediment quality over time, (iv) their diverse species have different life history characteristics and stress tolerances; (v) they play an important role in nutrient cycling, as links to higher trophic levels (birds and fish) and some are prey for commercially important species; and (vi) they influence the flow of chemicals between the water column and sediments through bioturbation and suspension feeding activities (Teixeira, 2010).

\section{Metagenomic SEquencing DISCOVERY OF BIODIVERSITY OF MARINE MICRO ORGANISMS}

Aquatic microbial diversity is vast, making it challenging to understand how the metabolism and interactions of individual organisms influence microbial community dynamics and biogeochemical transformations at the ecosystem level (Grossart et al., 2020). Conventionally, their biodiversity is decomposed into scale-dependent mathematical metrics representing alpha $(\alpha)$-diversity (diversity within a sample), beta ( $\beta$ )-diversity (community turnover), and gamma $(\gamma)$-diversity (regional diversity) (Props et al., 2016). Rapid advances in microecological methods have improved understanding of the vast biodiversity of microorganisms in aquatic communities (Hugerth and Andersson, 2017). Emerging advanced molecular techniques, combined with computational power, are lowering the cost of whole-genome DNA sequencing and opening opportunities for applied marine microbial research 
(Davenport and Tümmler 2013). For example, whole-genome next-generation sequencing (WMGS) has enabled more in-depth studies to delineate a broader range of microbial species taxa from environmental samples (Meyer et al., 2019). To quantify benthic microecological diversity, ampliconbased high-throughput sequencing technologies based on interspecific differences in single marker genes (16S rRNA) are widely used (Figure 3) (Props et al., 2016). These amplicon sequencings target the small-subunit ribosomal RNA (16S) locus, which is a taxonomically informative marker and shows that there is considerable microbial diversity within marine ecosystems (Birtel et al., 2015). 16S rRNA cloning techniques have accelerated the ability to describe species using a known reference library (Jovel et al., 2016). This new frontier makes it easier to classify community structure directly from marine environmental samples, rather than through laboratory-based culturing methods. These methodological developments enabled a new era of discovery to quantify the biodiversity of marine microorganisms and screen for the potential of natural products (Johnson et al., 2019).

Over the past three decades, microbial ecologists have increasingly used 16S rRNA as a marker gene to differentiate between microbial taxa, and the growing number of sequences in publicly available reference databases makes taxa identifications from 16S rRNA sequences more reliable (Birtel et al., 2015). Several bioinformatics tools have been developed to analyze the metagenomic data at the molecular level; as16S ribosomal DNA (rDNA), species level and strain level. The rDNA sequencing strategy is considered one of the most common approaches to understand microbial taxonomy and phylogeny; due to the stable functions of the rDNA gene over time, its existence in almost all microorganisms, and its sufficient size for bioinformatics analysis (Shuikan et al., 2019). A number of bioinformatics tools are available for rDNA analysis, including QIIME, MOTHUR, DADA2, UPARSE, and Minimum Entropy Decomposition (MED) (Niu et al., 2018). QIIME software is designed to analyze data generated on the Illumina or other NGS platforms using graphs and statistics. This includes multiplexing and quality filtering, operational taxonomic unit (OTU) picking, taxonomic assignment and phylogenetic reconstruction, and diversity analyzes and visualizations. QIIME is based on the PyCogent toolkit for misidentification and database storage using raw sequencing results (Shuikan et al., 2019). OTUs are generated from NGS data using UPARSE software, which works by filtering and trimming reads to equal lengths, removing singleton reads, and clustering the remaining reads (Edgar, 2013).

On the other hand, in the last two decades, there have been a number of early studies and large-scale investigations based on $18 \mathrm{~S}$ ribosomal DNA (rDNA) amplicon data that indicated a large microbial eukaryotic diversity and relevant novelty in different oceanic regions (Smith et al., 2020; Forster et al., 2019; Giner et al., 2019; Xue et al., 2018; Pernice et al., 2016; Edgcomb et al., 2002; LópezGarcía, et al., 2001; Moon-Van Der Staay et al., 2001; Pedrós-Alió, C. (2006).

However, recent rDNA amplicon data that depend on polymerase chain reaction (PCR) introduce biases into microbial diversity estimates and potentially affect both the number and relative abundance of species and taxonomic groups (Giner et al., 2016). In addition, high-throughput sequencing assays (HTS) that require the selection of a specific $18 \mathrm{~S}$ rDNA region for amplification with the hypervariable regions V9 and V4 are most commonly used, although in some cases they yield different results (Giner et al., 2020).

In the last decade, culture-independent studies of marine picoeukaryotic diversity based on $18 \mathrm{~S}$ ribosomal DNA clone libraries have revealed numerous sequences from new high-ranking taxa. This newly discovered diversity has significantly changed the understanding of marine microbial food webs and eukaryote evolution (Not et al., 2009). The18S rDNA clone libraries are considered the gold standard for conducting molecular studies of marine protist diversity in the environment. This has been conducted exclusively in the picoplanktonic size fraction $(0.2-3 \mathrm{~mm})$, examining unveiled high-ranking taxa; such as marine alveolates (MALV), marine stramenopiles (MAST) and picobiliphytes (Not et al., 2007). Analysis of marine $18 \mathrm{~S}$ rDNA sequences shows that marine protists are highly diverse and significantly increase the known diversity within the eukaryotic tree of life (Massana and Pedrós-Alió, 2008). In different marine regions, diversity surveys of picoplanktonic protists reveal broadly similar patterns (Worden and Not, 2008), with a dominance of non-photosynthetic groups, including minute parasites and grazers (Not et al., 2009). Metabarcoding of 16S and 18S rRNA genes was used to examine the abundances of operational taxonomic units and taxonomic groups (and their ratios) to provide information on the ecological quality of coastal waters. Furthermore, these techniques showed 
that only eukaryotic diversity metrics and a limited number of prokaryotic and eukaryotic taxa were effective for continental influences, resulting in limited potential of microbial plankton diversity as an ecological indicator. Therefore, the inclusion of microbial plankton diversity in environmental assessment may not always lead to significant improvement in current marine monitoring strategies (Nurul et al., 2019).

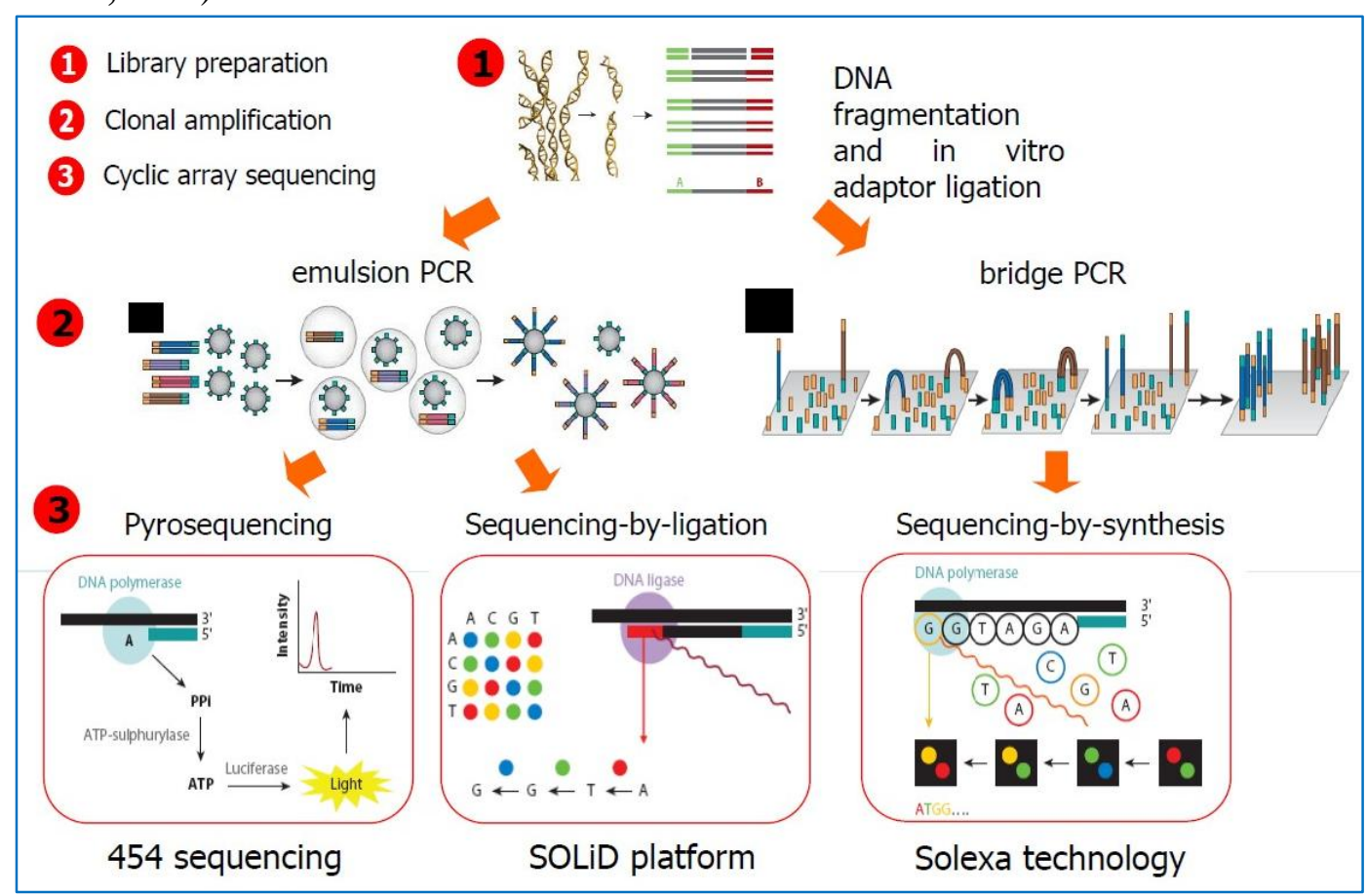

Figure3. Types of analyses of Next-generation DNA sequencing platforms.

Metagenomics is revolutionizing the study of microorganisms and their involvement in biological, biomedical, and geochemical processes; it allows direct sequencing of an enormous variety of organisms without the need for prior cultivation (Karin et al., 2020). Metagenomes use massive shotgun sequencing of genomic DNA extracted from microbial assemblages to assess their functional metabolic potential. Given the utility and general application of $18 \mathrm{~S}$ rDNA, a metagenome goes handin-hand with the fact that identification of 18SrDNA sequences within metagenomes elucidates microeukaryotic diversity, free from the potential biases of PCR-dependent methods. This technique has been used previously with shotgun Sanger sequencing data from the Global Ocean Survey (GOS) (Not et al., 2009). The sequencing depth achievable at that time allowed recovery of low signal, with only $116 \mathrm{18S}$ rDNA fragments found in the complete GOS dataset (Obiol et al., 2020). With the avalanche of metabarcoding data, statistical synthesis of relevant literature to develop evidence-based inferences (meta- or secondary analysis) has become a powerful tool; to solve microbial community structure and ecology (ArchMiller et al., 2015). HTS technologies provide interrogation of a small portion of the gene encoding the SSU rRNA and the target region varies depending on the study (V3, V4 or V9). The portion of the variable zone targeted influences the assessment of the richness, diversity, and composition of the microbial community, including prokaryotes and eukaryotes (Debroas et al., 2017). For easier and more accurate taxonomic identification, focusing on the V4 sequences is preferable as this is a larger dataset (Dunthorn et al., 2012). Metabarcoding; an alternative approach to amplicon based HTSones; to study microbial diversity, involves exploiting the taxonomic information contained in metagenomes. These use massive shotgun sequencing of genomic DNA extracted from microbial assemblages to determine their functional metabolic potential (Obiol et al., 2020). Given the utility and general application of $18 \mathrm{~S}$ rDNA, it follows that identification of $18 \mathrm{~S}$ rDNA sequences within metagenomes provides a pathway to resolving microeukaryotic diversity free from the potential biases of PCR-dependent methods. The development of HTS platforms and the reduction in sequencing costs have enabled a dramatic increase in sequencing depth and grant the recovery of significant numbers of short $18 \mathrm{~S}$ rDNA metagenome reads from the sample (metagenomic Illumina Tags or miTags; mTags) (Goodwin et al., 2016). Several tools developed for extracting these reads are based on 16S/18S rDNA Hidden Markov Model (HMM) profiles (Gruber-Vodicka et al., 2019). 
Although some studies have used HMM profiles to assess the diversity of eukaryotic organisms in different environments, as reported by Saghaï et al., (2015), Pernice et al., (2016); Bahram et al., (2018); Guajardo-Leiva et al., (2018), it remains a challenge to obtain an accurate taxonomic classification of the short metagenomic reads (100-250 bp) (Breitwieser et al., 2019), especially when targeting the $18 \mathrm{~S}$ rDNA gene, which contains a mosaic of highly conserved and highly variable regions (Obiol et al., 2020). Bioinformatics tools can address this problem (Guo et al., 2016); by maintaining the highest unique level in hierarchical taxonomic classifications, but still heavily depend on good reference databases for correct taxonomic assignment (Murali et al., 2018).

A metagenomics is a PCR-free approach that contains all genetic information from microbial assemblages. Nowadays, it is performed on a relatively large scale and at a reasonable cost and is usually based on very short reads. Metagenomics is an emerging technology for detecting life in the most extreme environments; from the discovery of hydrothermal vents in the deep sea to the study of marine biodiversity, particularly microorganisms.

Another important goal of microbial ecology is to observe, detect, and predict the spatial and temporal distribution and interrelationships of microorganisms in the environment. When different microbial species are taxonomically profiled, it is often found that large unidentified differences occur in aquatic ecosystems, both spatially and temporally. Variation in gene content (assessed by metagenomics) often reveals complex interactions between metabolic processes and environmental factors (Grossart et al. 2019). The strength of the relationships depends on the extent of environmental transition between populations. However, there are important problems in microbial ecology. Many taxa that are redundant at the metabolic pathway level exhibit a great deal of environmental heterogeneity in different ecological environments. There are several potential hypotheses, including ecosystem constraint, biotic interactions, and rapid responses to evolving environmental factors that cannot be readily predicted by gene content alone (Figure 4).

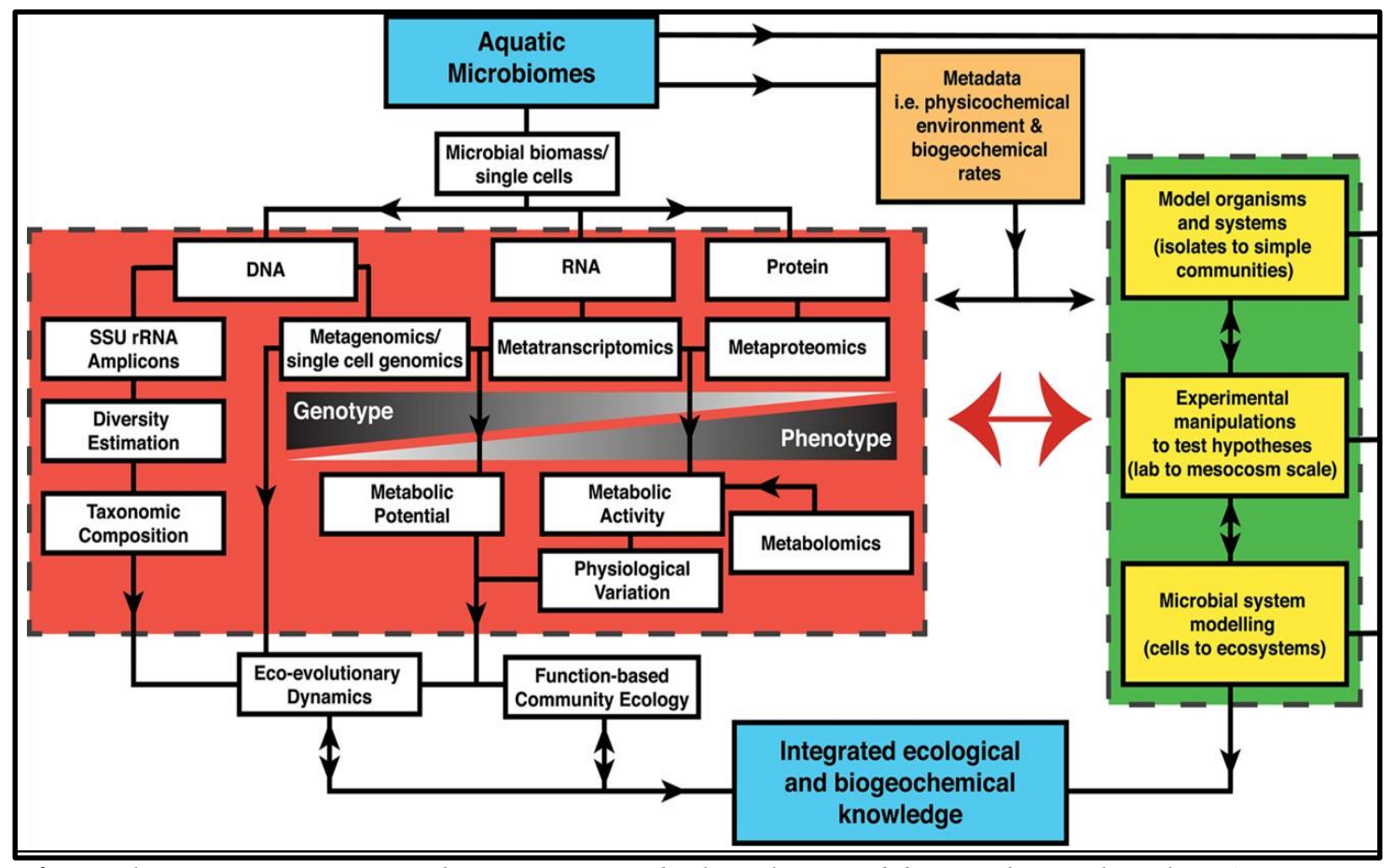

Figure4. Linking metagenomics with aquatic microbial ecology and biogeochemical cycles: A conceptual framework for integrating the diversity of metagenomics approaches into advanced studies of aquatic microbial ecology and biogeochemistry as presented in the contributions to this special issue. Figure adapted from Grossart et al., (2019).

\section{Predictive Metabolomic Profiling of Microbial Communities}

The association between phylogeny and functional capabilities relies on the complexity of traits, as shown by Langille et al., (2013), who find that phylogeny is strongly associated with functional capabilities. This implies that reliably predicting organism functions embedded in their genome is a valid method (Langille et al., 2013). As such, functional profile prediction using marker gene data can 
be very helpful as it greatly decreases the amount of data needed to provide a general look at the functional profile of the microbial population. It is important to point out, however, that attempting to decode functional profiles using amplicon-based metagenomics does not fully replace shotgun sequencing. More precisely, if a higher degree of practical precision and certainty is needed, then shotgun sequencing should be performed. However, in many cases, amplicon-based sequencing will either speed up or prolong the process of performing more in-depth studies such as shotgun metagenomics, metatranscriptomics, and metaproteomics (Figure 5).

Recent computational applications include PICRUSt, Tax4Fun, and Vikodak, both of which can predict the functional profiles of arbitrary microbial populations based on 16S rRNA data. Because these novel predictive systems provide information about the nature of the metagenome without resorting to shotgun sequencing, they have gained wide acceptance in the scientific community. The software tool developed by Langille et al., (2013) is called Phylogenetic Investigation of Communities by Reconstruction of Unobserved States (PICRUSt) and estimates functional profile based on targeted metagenomic data (16S rRNA). The microbial profile prediction method is performed in two stages: (i) "gene content inference", which is generated from each organism in a phylogenetic tree as a reference; then the system generates a table with the expected abundance of gene families for each member of the microbial community and (ii) "metagenome inference", at this point the system multiplies the abundance of $16 \mathrm{~S}$ rRNA genes among all microbial taxa in the sample. The results are corrected by first measuring the number of copies of the 16S rRNA gene identified for each taxon and then sorting the gene abundance by family. This technology is unique in that it is capable of recognizing genes even though they have not yet been fully sequenced. This mechanism is conducted by means of genes which are found in evolutionary ancestors (previously sequenced). PICRUSt depends on current gene annotations and the number of 16S rRNA copies identified for individual genomes in order to achieve this goal (Douglas et al. 2020).

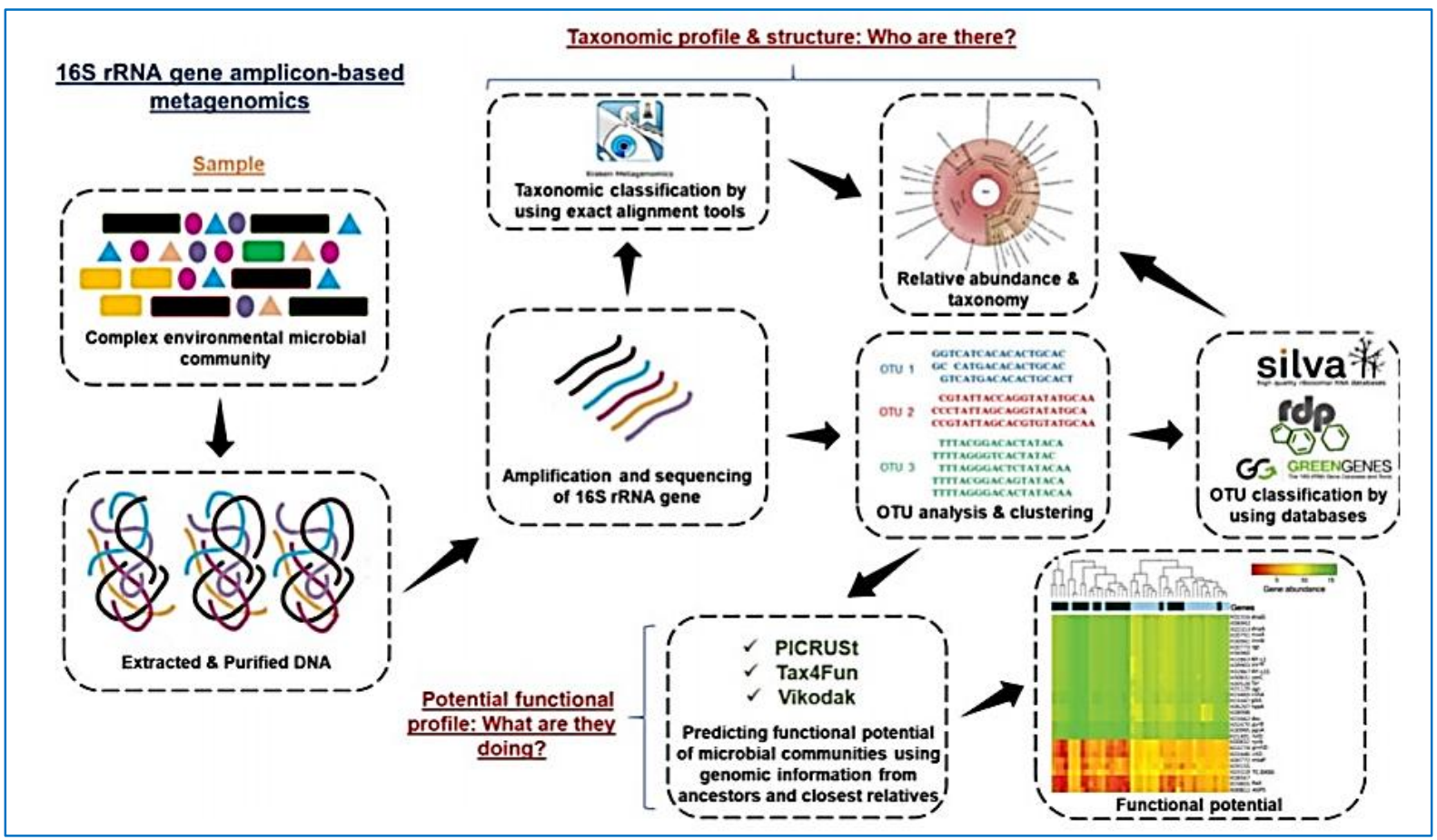

Figure5. General pipeline and bioinformatic tools considered for the analysis of metagenomic 16S rRNA data sets to obtain taxonomic and functional profiles from any complex environmental microbial community. Figure adapted from Morgan \& Huttenhower (2012).

\section{CONCLUSION}

Currently, NGS technology is mainly used in metagenomic studies to investigate the diversity, composition and functionality of the microbial community. Moreover, these innovations have recently been applied in aquaculture microbiome studies, microbial diversity, bioremediation, pollution monitoring, enzyme and drug discovery. Although data obtained after sequencing taxonomic marker genes provide deeper insight into the taxonomic diversity of microbial communities that thrive in any 
environmental sample, 5 years ago this information was not adequate to make adequate predictions about the functional potential of these communities. However, this has changed thanks to the development of powerful and robust bioinformatics tools that allow prediction of the functional profile. The most important and novel feature of this approach is that the same data obtained after sequencing taxonomic marker genes can be used with an acceptable degree of confidence to generate a predictive functional profile. A greater advantage of these predictive programmes is that they allow the potential functional profile to be known without the need for shotgun sequencing. At the same time, costs are reduced and studies are focused on the analysis of specific metabolic pathways present in environmental samples, even if these are from rare or artificial environments and the genomes of these microbial community members are not yet available.

\section{REFERENCES}

[1] Abrogueña, J.B.R., Joydas, T.V., Pappathy, M., Cali, N.A., Alcaria, J., Shoeb, M. (2020): Structure and composition of the macrobenthic community associated to shallow mangrove-sea grass habitat along the southern Red Sea coast, Saudi Arabia. Egy. J. Aqua. Res. (National Institute of Oceanography and Fisheries Production and hosting), Elsevier B.V., 6 pages. https://doi.org/10. 1016/ j. ejar.2020.10.001

[2] Alsaffar, Z.H. (2018): Shallow soft sediment communities in the central red sea: revealing patterns in community structure across space and time. PhD dissertation, King Abdullah University of Science and Technology, Thuwal, KSA.

[3] Alsaffar, Z., Cúrdia, J., Borja, A., Irigoien, X., Carvalho, S. (2019): Consistent variability in beta-diversity patterns contrasts with changes in alpha-diversity along an onshore to offshore environmental gradient: The case of Red Sea soft-bottom macrobenthos. Mar. Biodiv., 49, 247-62.

[4] ArchMiller, A.A., Bauer, E.F., Koch, R.E., Wijayawardena, B.K., Anil, A., Kottwitz, J.J., Munsterman, A.S., Wilson, A.E. (2015): Formalizing the definition of meta-analysis in molecular ecology. Mol. Ecol., 24 (16), 4042- 51.

[5] Armenteros, M., Saladrigas, D., González-Casuso, L., Estevez, E.D., Kowalewski, M. (2018): The role of habitat selection on the diversity of macrobenthic communities in three gulfs of the Cuban Archipelago. Bull. Mar. Sci. (School of Marine and Atmospheric Science, University of Miami, Florida, USA, 94 (2), 21 pages.

[6] Bahram, M., Hildebrand,F., Forslund, S.K., Anderson, J.L., Soudzilovskaia, N. A., Bodegom, P.M., Bengtsson-Palme, J., Anslan, S., Coelho, L.P., Harend, H., Huerta-Cepas, J., Medema, M.H., Maltz, M.R., Mundra, S., Olsson, P.A., Pent, M., Põlme, S., Sunagawa, S., Ryberg, M., Tedersoo, L., Bork, P. (2018): Structure and function of the global topsoil microbiome. Nat., 560 (7717), 233-7.

[7] Belal, A.A.M., El-Sawy, M.A., Dar, M.A. (2016): The effect of water quality on the distribution of macrobenthic fauna in Western Lagoon and Timsah Lake, Egypt. I. Egypt. J. Aqua. Res., 42 (4), 437-48

[8] Berumen, M.L., Hoey, A.S., Bass, W.H., Bouwmeester, J., Catania, D., Cochran, J.E.M., Khalil, M.T., Miyake, S., Mughal, M.R., Spaet, J.L.Y., Saenz-Agudelo, P. (2013): The status of coral reef ecology research in the Red Sea. Coral Reefs, 32, 737-48. https://doi.org/10.1007/s00338-013-1055-8

[9] Berumen, Michael L.; Voolstra, C.R., Daffonchio, D., Agusti, S., Aranda, M., Irigoien, X., Jones, B.H., Morán, X.A.G., Duarte, C.M. (2019): The Red Sea: Environmental Gradients Shape a Natural Laboratory in a Nascent Ocean. In: Coral Reefs of the Red Sea: Coral Reefs of the World, Voolstra C., Berumen M. (eds), vol. 11. Springer, Cham.

[10] Birtel, J., Walser, J.C., Pichon, S., Bürgmann, H., Matthews, B. (2015): Estimating bacterial diversity for ecological studies: Methods, metrics and assumptions. PLoS One, 10 (4), 23 pages. https://doi.org/10.1371/journal.pone. 0125356.

[11] Biswas, S.R., Mallik, A.U., Braithwaite, N.T., Wagner, H.H. (2016): A conceptual framework for the spatial analysis of functional trait diversity. Oikos., 125, 192-200.

[12] Breitwieser FP, Pertea M, Zimin AV, Salzberg SL. Human contamination in bacterial genomes has created thousands of spurious proteins. Genome Res. 2019 Jun;29(6):954-960. doi: 10.1101/gr.245373.118. Epub 2019 May 7. PMID: 31064768; PMCID: PMC6581058.

[13] Bruckner, A., G. Rowlands, B. Riegl, S. Purkis, A. Williams, and P. Renaud (2012) Khaled bin Sultan Living Oceans Foundation Atlas of Saudi Arabian Red Sea Marine Habitats. Panoramic Press, pp. 262.

[14] Caron, D.A., Countway, P.D., Jones, A. C., Kim, D.Y., Schnetzer, A. (2012): Marine protistan diversity. Ann. Rev. Mar. Sci., 4 (1), 467-93.

[15] Carradec, Q., Pelletier, E., Da Silva, C., Alberti, A., Seeleuthner, Y., Blanc-Mathieu, R.., Lima-Mendez, G., Rocha, F., Tirichine, L., Labadie, K., Kirilovsky, A., Bertrand, A., Engelen, S., Madoui, M.A., Méheust, R., Poulain, J., Romac, S., Richter, D.J., Yoshikawa, G., Dimier C., Kandels-Lewis, S., Picheral, M., Searson, S; Tara Oceans Coordinators, Jaillon, O., Aury, J.M., Karsenti, E., Sullivan, M.B., Sunagawa, S., Bork, P., Not, 
F., Hingamp, P, Raes, J., Guidi, L., Ogata, H., de Vargas, C., Iudicone, D., Bowler, C., Wincker, P. (2018): A global ocean atlas of eukaryotic genes. Nat. Commun., 25, 9 (1), 373, 13 pages

[16]Dang, H., and Lovell, C.R. (2016): Microbial surface colonization and biofilm development in marine environments. Microbiol. Mol. Biol. Rev., 80, 91-138.

[17] Davenport, C.F., and Tümmler, B. (2013): Advances in computational analysis of metagenome sequences. Environ. Microbiol., 15, 1-5.

[18] Debroas, D., Domaizon, I., Humbert, J.-F., Jardillier, L., Lepère, C, A., Oudart, A., Taïb, N. (2017): Overview of freshwater microbial eukaryotes diversity: A first analysis of publicly available metabarcoding data. FEMS Microb. Ecol., 93 (4). 14 pages. https://doi.org/10.1093/femsec/fix023.

[19] DiBattista J.D., Choat J.H, Gaither M.R., Hobbs P.A., Lozano-Cortes D. F., Myers R.F., Paulay G., Rocha L.A., Toonen R. J., Westneat M.W. and Berumen M.L. (2016). On the origin of endemic species in the Red Sea. Journal of Biogeography 43, 13-30.

[20]Douglas, G.M., Maffei, V.J., Zaneveld, J.R. et al. (2020). PICRUSt2 for prediction of metagenome functions. Nat Biotechnol 38, 685-688. https://doi.org/10.1038/s41587-020-0548-6

[21] Dreano, D., Raitsos, D. E., Gittings, J., Krokos, G., Hoteit, I. (2016): The Gulf of Aden intermediate water intrusion regulates the southern Red Sea Summer phytoplankton blooms. PloSOne, 11 (12), 334-78. https://doi.org/10.1371/jour-nal.pone.0168440.

[22] Dunthorn, M., Klier, J., Bunge, J., Stoeck, T. (2012): Comparing the hyper-variable V4 and V9 regions of the small subunit rDNA for assessment of ciliate environmental diversity. J. Eukar. Microbiol., 59 (2), 185 -. https://doi.org/10.1111/j.1550-7408.2011.00602.x

[23] Dupuy, C., Nguyen, H.T., Mizrahi, D., Jourde, J., Bréret, M., Agogué, H., Beaugeard, L., Bocher, P. (2015): Structure and functional characteristics of the meiofauna community in highly unstable intertidal mudbanks in Suriname and French Guiana (North Atlantic coast of South America). Continental Shelf Research, Elsevier, 41 pages. ff10.1016/j.csr.2015.09.019ff. ffhal-01243550f.

[24]Edgar, R.C. (2013): UPARSE: Highly accurate OTU sequences from microbial amplicon reads. Nat. Meth., 10, 996-8.

[25] Edgcomb, V.P. (2016). Marine protist associations and environmental impacts across trophic levels in the twilight zone and below. Curr. Opin. Microb., 31, 169-75.

[26]Edgcomb, V.P., Kysela, D.T., Teske, A., de Vera Gomez, A., Sogin, M.L. (2002): Benthic eukaryotic diversity in the Guaymas Basin hydrothermal vent environment. Proceed. Nat. Acad. Sci., 99 (11), 7658- 62.

[27]El Raey, M. (2010): Impact of sea level rise on the Arab region. Arab Academy of Science, Technology and Maritime Transport, Regional Center for Disaster Risk Reduction, Alexandria University, ARE, 89 pages. https://www.preven-tionweb.net/ go/17005

[28]Ellis, J., Anlauf, H., Kürten, S., Lozano-Cortés, D., Alsaffar, Z., Cúrdi, J., Jones, B., Carvalho, S. (2017): Cross shelf benthic biodiversity patterns in the Southern Red Sea. Sci. Rep., 7 (437), 14 pages.

[29] Ferraro, S.P. (2013): Ecological periodic tables: in principle and practice. Oikos., 122, 1541-53.

[30] Fine, M. Cinar, M., Voolstra, C.R., Safa, A., Rinkevich, B., Laffoley, D., Hilmi, N., Allemand, D. (2019): Coral reefs of the Red Sea: Challenges and potential solutions. Reg. Stud. Mar. Sci., 25,100498 , https://www.sciencedirect.com/science/ article/pii/S235248551830519X.

[31]Forster, D., Filker, S., Kochems, R., Breiner, H.W., Cordier, T., Pawlowski, J., Stoeck, T. (2019): A comparison of different ciliate metabarcode genes as bioindicators for environmental impact assessments of salmon aqua-culture. J. Eukar. Microb., 66 (2), 294-308.

[32] Ghasemi, A.F. and Kamali, M. (2014). Benthic Macroinvertebrates along the Haraz Downstream in Southern Caspian Sea Basin: In Gradient of the Physicochemical Parameters. International Journal of Zoology, 2014, Article ID 145430.

[33] Giere, O. (2009): Meiobenthology: The microscopic fauna in aquatic sediments. $2^{\text {nd }}$ edn., Berlin, Germany, Springer Verlag, 538 Pages.

[34] Giner, C.R., Forn, I., Romac, S., Logares, R., de Vargas, C., Massana, R. (2016): Environmental sequencing provides reasonable estimates of the relative abundance of specific picoeukaryotes. Appl. Environ. Microbiol., 82 (15), 4757-66.

[35] Giner, C.R., Balagué, V., Krabberød, A.K., Ferrera, I., Reñé, A., Garcés, E., Gasol, J.M., Logares, R., Massana, R. (2019): Quantifying long-term recurrence in planktonic microbial eukaryotes. Mol. Ecol., 28 (5), 923-935.

[36] Giner, C.R., Pernice, M. C., Balagué, V., Duarte, C.M., Gasol, J.M., Logares, R., Massana, R. (2020): Marked changes in diversity and relative activity of pico-eukaryotes with depth in the world ocean. ISME J., 14 (2), 437- 49. 
[37] Goodwin, S., McPherson, J.D., McCombie, W.R. (2016): Coming of age: Ten years of next-generation sequencing technologies. Nat. Rev. Genet., 17 (6), 333-51. https://doi.org/10.1038/nrg.2016.49

[38] Graham, E.B., Knelman, J.E., Schindlbacher, A., Siciliano, S., Breulmann, M., Yannarell, A., Beman, J.M., Abell, G., Philippot, L., Prosser, J., Foulquier, A., Yuste, J.C., Glanville, H.C., Jones, D.L., Angel, R., Salminen, J., Newton, R.J., Bürgmann, H., Ingram, L.J., Hamer, U., Siljanen, H.M.P., Peltoniemi, K., Potthast, K., Bañeras, L., Hartmann, M., Banerjee, S., Yu, R.-Q., Nogaro, G., Richter, A., Koranda, M., Castle S.C., Goberna, M., Song, B., Chatterjee, A., Nunes, O.C., Lopes A.R., Cao Y., Kaisermann, A., Hallin S., Strickland M.S., Garcia-Pausas, J., Barba, J., Kang H., Isobe, K., Papaspyrou, S., Pastorelli, R., Lagomarsino, A., Lindström, E.S., Basiliko, N., Nemergut, D.R. (2016): Microbes as Engines of Ecosystem Function: When Does Community Structure Enhance Predictions of Ecosystem Processes? Front. Microbiol. 7, 214, 10 pages. https://doi.org/10. 3389/fmicb.2016.00214

[39] Grossart, H.P., Massana, R., McMahon, K.D., Walsh, D.A. (2020): Linking metagenomics to aquatic microbial ecology and biogeochemical cycles. In: Limnol. Oceanogr., 65 (S1), S2-20.

[40] Gruber-Vodicka, H.R., Seah, B.K., Pruesse, E. (2019): phyloFlash: Rapid SSU rRNA profiling and targeted assembly from metagenomes. BioRxiv, 521922. https://doi.org/10.1101/521922

[41] Guajardo-Leiva S., Pedrós-Alió C., Salgado O., Pinto F., Díez B. (2018). Active crossfire between Cyanobacteria and Cyanophages in phototrophic mat communities within hot springs Front. Microbiol., 9, 2039, 10.3389/fmicb.2018.02039

[42] Guo, F., Yu, J., Jung, H.J., Abruzzi, K.C., Luo, W., Griffith, L.C., Rosbash, M. (2016). Circadian neuron feedback controls the Drosophila sleep--activity profile. Nature 536(7616): 292--297.

[43] Haeckel E., (1891). Haeckel E. Plankton-Studien. Jenaische Zeitschrift für Naturwissenschaft.25:232-336.

[44] Hariri, M.S.B. (2012): The present status of the Red Sea coral reefs between Haql and Yanbu, Saudi Aarabia. Life Sci. J., (4), 3852-9.

[45] Henselera, C., Nordströma, M.C., Törnroosa, A., Snickarsa, M., Pecucheta, L., Lindegrenc, M., Bonsdorf, E. (2019): Coastal habitats and their importance for the diversity of benthic communities: A species- and traitbased appr-oach. Estuarine, Coas. Shel. Sci. j., 15 pages. https://doi.org/10.1016/j.ecss. 2019.106272

[46] Holzhauer, H., Borsje, B.W., van Dalfsen, J.A., Wijnberg, K.M., Hulscher, S.J., Herman, P.M. (2020): Benthic species distribution linked to morphological features of a barred coast. J. Mar. Sci. Eng., 8 (1), 16, 23 pages.

[47] Hugerth, L.W., Andersson, A.F. (2017): Analyzing microbial community composition through amplicon sequencing: from sampling to hypothesis testing. Front. Microbiol., 8, 1-22.

[48] Ingels, Jeroen; Valdes, Yirina; Pontes, Letícia P.; Silva, Alexsandra C.; Neres, Patrícia F.; Corrêa, Gustavo V.V.; Silver-Gorges, Ian; Fuentes, Mariana M.P.B.; Gillis, Anthony; Hooper, Lindsay; Ware, Matthew; O’Reilly, Carrie; Bergman, Quintin; Danyuk, Julia; Sanchez Zarate, Sofia; Acevedo Natale, Laura I.; dos Santos, Giovanni A.P. 2020. "Meiofauna Life on Loggerhead Sea Turtles-Diversely Structured Abundance and Biodiversity Hotspots That Challenge the Meiofauna Paradox" Diversity 12, no. 5: 203. https://doi.org/10.3390/d12050203

[49] Johnson, J.S., Spakowicz, D.J., Hong, BY. et al. Evaluation of 16S rRNA gene sequencing for species and strain-level microbiome analysis. Nat Commun 10, 5029 (2019). https://doi.org/10.1038/s41467-019-130361

[50] Jovel, J., Patterson, J., Wang, W., Hotte, S., O’Keefe, N., Mitchel, T., Perry, T., Kao, D., Mason, A.L., Madsen, K.L., Wong, G.K. (2016): Characterization of the gut microbiome using 16S or shotgun metagenomics. Front. Microbiol., 7, 459, 17 pages. https://doi.org/10. 3389/fmicb.2016.00459.

[51] Joydas, T.V., and Borja, A. (2019): Benthic Ecosystems (Soft and hard substrata). Chap.3, In: ecosystems and biodiversity of the Arabian Gulf-Saudi Arabian waters: 50 years of Marine Research, edited by AlAbdulkader, K., Loughland, R.A., Qurban, M.A., Published by Saudi Aramco and King Fahd University of Petroleum and Minerals, 222-53. https://www.researchgate.net/publication/ 334469198.

[52] Joydas, T.V., Qurban, M.A.B., Karuppasamy, M., Rabaoui, L., Periyadan K., Kishnakumar, P.K. (2019): Spatial patterns of standing stock and diversity of macrobenthic communities in the Red Sea. Chap. 19, In: Oceanographic and Biological Aspects of the Red Sea, Springer Oceanography (Part of the Springer Oceanography book series; SPRINGEROCEAN), N. M. A. Rasul

[53] Joydas, T.V., Qurban, M.A., Ali, S.M., Albarau, J.F., Rabaoui, L., Manikandan, K.P., Krishnakumar, P.K. (2018): Macrobenthic community structure in the deep waters of the Red Sea. Deep-Sea Res. (Part I), 137, 38-56.

[54] Karin, E.L., Mirdita, M., Söding, J. (2020): MetaEuk: Sensitive, high-through-put gene discovery and annotation for large-scale eukaryotic meta-genomics. Microbiome, 8, 48, 15 pages. https://doi.org/10.1186/s40168-020-00808-x. 
[55] Kellogg, C., Deming, J. (2014): Particle-associated extracellular enzyme activity and bacterial community composition across the Canadian Arctic Ocean, FEMS Microb. Ecol., 89 (2), 360-75.

[56] Khalil, M.T., Bouwmeester, J., Berumen, M. L. (2017). Spatial variation in coral reef fish and benthic communities in the central Saudi Arabian Red Sea. PeerJ, 5, e3410.

[57] Kraft, N.J.B., Adler, P.B., Godoy, O., James, E.C., Fuller, S., Levine, J.M. (2015): Community assembly, coexistence and the environmental filtering metaphor. Funct. Ecol., 29, 592-9.

[58] Langille, M., Zaneveld, J., Caporaso, J. et al. Predictive functional profiling of microbial communities using 16S rRNA marker gene sequences. Nat Biotechnol 31, 814-821 (2013). https://doi.org/10.1038/nbt.2676

[59]Li B., Li X., Bouma T. J., Soissons L.M., Cozzoli F., Wang Q., Zhou Z., Chen L. (2017). Analysis of macrobenthic assemblages and ecological health of Yellow River Delta, China, using AMBI \& M-AMBI assessment method. Marine Pollution Bulletin, 08505; 10.

[60] López-García, P., López-López, A., Moreira, D., Rodríguez-Valera, F. (2001): Diversity of free-living prokaryotes from a deep-sea site at the Antarctic Polar Front. FEMS Microbiol. Ecol., 36 (2-3),193-202.

[61] Martinez-Porchas, M., Martinez-Cordova, L. R. (2012): World aquaculture: Envi-ronmental impacts and troubleshooting alternatives. Sci. Wor. J., 9 pages. https://doi. org/10.1100/2012/389623

[62] Massana, R., Pedros-Alio, C. (2008): Unveiling new microbial eukaryotes in the surface ocean. Curr. Opin. Microb., 11(3), 213-8.

[63] Meyer F, Bremges A, Belmann P, Janssen S, McHardy AC, Koslicki D. (2019). Assessing taxonomic metagenome profilers with OPAL. Genome Biol. Mar 4;20(1):51.

[64] Monroe, A.A., Ziegler, M., Roik, A., Ro“thig, T., Hardenstine, R.S., Emms, M.A., Jensen, T., Voolstra, C.R., Berumen, M.L. (2018): In situ observations of coral bleaching in the central Saudi Arabian Red Sea during the 2015/2016 global coral bleaching event. PLoS ONE, 13 (4), e0195814, 13 pages. https://doi. org/10.1371/journal.pone. 0195814

[65] Moon-van der Staay SY, De Wachter R, Vaulot D. (2001). Oceanic 18S rDNA sequences from picoplankton reveal unsuspected eukaryotic diversity. Nature. 409:607-610.

[66] Moreyra, A.K., Padovesi-Fonseca, C. (2015): Environmental effects and urban impacts on aquatic macroinvertebrates in a stream of central Brazilian Cerrado. Sustain. Water Resour. Manag., 1, 125-36.

[67] Morgan XC, Huttenhower C. Chapter 12: Human microbiome analysis. PLoS Comput Biol. 2012;8(12):e1002808.

[68] Mosbahi, N., Serbaji, M.M., Pezy, J.-P., Neifar, L., Dauvin, J.-C. (2019): Response of benthic macrofauna to multiple anthropogenic pressures in the shallow coastal zone south of Sfax (Tunisia, central Mediterranean Sea). Environ. Poll., 253, 474-87. https://www.sciencedirect.com/science/article/pii/S0269749119307687.

[69] Moyo, R., Pillay, D., Baeza, J.A. (2017): Symbiont-mediated shifs in sand prawn behavior: Implications for ecosystem functioning in marine soft-sediment ecosystems. J. Exp. Mar. Biol. Ecol., 486, 296-304.

[70] Nanninga, G.B., Saenz-Agudelo, P., Manica, A., Berumen, M.L. (2014): Environ-mental gradients predict the genetic population structure of a coral reef fish in the Red Sea. Mol. Ecol., 23, 591-602.

[71]Naskar, A.R. (2019): Benthos: Types and their role in ecosystem. Lectures for students in Zoology Department and Applied Aquaculture, Barkatullah University, Bhopal, India, Retrieved on 7/7/2019, from: https://www2.slide-share.net/featured/category/ science.

[72] Ncube, S., Visser, A., Beevers, L.A. (2018): Framework for assessing instream supporting ecosystem services based on hydroecological modeling. Water, 10, 124, 25 pages.

[73] Niu, S.Y., Yang, J., Mc Dermaid, A., Zhao, J., Kang, Y., Ma, Q. (2018): Bioinformatics tools for quantitative and functional metagenome and metatranscriptome data analysis in microbes. Brief. Bioinform. 19 (6), 141529.

[74] Not, F., Valentin, K., Romari, K., Lovejoy, C., Massana, R., Töbe, K., Vaulot, D., Medlin, L.K. (2007): Picobiliphytes: A marine picoplanktonic algal group with unknown affinities to other eukaryotes. Sci., 315 (5809), 253-5.

[75] Not, F., del Campo, J., Balagué, V., de Vargas, C., Massana, R. (2009): New insights into the diversity of marine picoeukaryotes into. PLoS ONE, 4 (9), e7143, 7 pages. https://doi.org/10.1371/ journal. pone. 0007143

[76] Nurul, A.N.A., Muhammad, D.-D.-., Okomoda, V.T., Bt. Nur, A.A. (2019): 16S rRNA-Based metagenomic analysis of microbial communities associated with wild Labroides dimidiatus from Karah Island, Terengganu, $\begin{array}{llll}\text { Malaysia. } & \text { Biotechnol. } & \text { Repo., } & \text { 21, }\end{array}$ https://www.sciencedirect.com/science/article/pii/S2215017X18302467. 
[77] Obiol, A., Giner, C.R., Sánchez, P., Duarte, C.M., Silvia G. Acinas, S.G., Massana, R. (2020): A metagenomic assessment of microbial eukaryotic diversity in the global ocean. Mol. Ecol. Resor., 20 (3), 718-31.

[78] Patrick, M.S., Jean-Marie, T.M., Nadine, M.L. (2015): Benthic macroinverte-brates as indicators of water quality: A case-study of urban funa stream (in Kinshasa, Democratic Republic of Congo). Open J. Wat. Poll. Treat., 2 (1), 8-24.

[79] Pedrós-Alió, C. (2006). Marine microbial diversity: Can it be determined? Trends in Microbiology, 14(6), 257-263

[80] Pernice, M.C., Giner, C.R., Logares, R., Perera-Bel, J., Acinas, S.G., Duarte, C.M., Gasol, J.M. Massana, R. (2016): Large variability of bathypelagic microbial eukaryotic communities across the world's oceans. ISME J., 10 (4), 945-58.

[81] Pillay, D. (2019): Ecosystem engineering by thalassinidean crustaceans: Response variability, contextual dependencies and perspectives on future research. Divers., 11, 64 (2019), 20 pages.

[82] Pinnell, L.J., and Turner, J.W. (2019): Shotgun metagenomics reveals the benthic microbial community response to plastic and bioplastic in a coastal marine environment. Front. Microbiol., 10,1252, 13 pages.

[83] Polinski, J.M., Bucci, J.P., Gasser, M., Bodnar, A.G. (2019): Metabarcoding assessment of prokaryotic and eukaryotic taxa in sediments from Stellwagen Bank National Marine Sanctuary. Sci. Rep., 9 (14820), 8 pages. https://doi.org/ 10.1038/ s41598-019-51341-3.

[84] Props, R., Monsieurs, P., Mysara, M., Clement, L., Boon, N. (2016): Measuring the biodiversity of microbial communities by flow cytometry. Method. Ecol. Evol., 7, 1376-85.

[85] Rasul, N.M.A., and Stewart, I.C.F. (2015): The Red Sea: The formation, morphology, oceanography and environment of a young ocean basin (Part of the Springer Earth System Sciences book series). 1 (1), SpringerVerlag Berlin Heidelberg, 638 pages. https://doi.org/10.1007/978-3-662-45201-1

[86] Rute Pinto, Joana Patrício, Alexandra Baeta, Brian D. Fath, João M. Neto, João Carlos Marques, (2009). Review and evaluation of estuarine biotic indices to assess benthic condition, Ecological Indicators. 9(1):125.

[87] Saghaï, A., Gutiérrez-Preciado, A., Deschamps, P., Moreira, D., Bertolino, P., Ragon, M., et al. (2017). Unveiling microbial interactions in stratified mat communities from a warm saline shallow pond. Environ. Microbiol. 19, 2405-2421.

[88] Savelli, R., Dupuy, C., Barillé, L., Lerouxe, A., Guizien, K., Philippe, A., Bocher, P., Polsenaere, P., Le Fouest, V. (2018): On biotic and abiotic drivers of the microphytobenthos seasonal cycle in a temperate intertidal mudflat: A modelling study. Biogeosci.,15, 7243-71.

[89] Shaltout, M. (2019): Recent sea surface temperature trends and future scenarios for the Red Sea. Oceanol., 61 (4), 484-504,

[90] Shuikan, A., Alharbi, S.A., Alkhalifah, D.H.M., Hozzein, W.N. (2019): High-throughput sequencing and metagenomic data analysis. Chapter 3, In: Metagenomics: Basics, methods and applications, Edited by Wael N. Hozzein, IntechOpen, 15 pages.

[91] Smith, P.E., Waters, S.M., Gómez Expósito, R., Smidt, H., Carberry, C.A., McCabe, M.S. (2020): Synthetic Sequencing Standards: A Guide to database choice for rumen microbiota amplicon sequencing analysis. Front. Microbiol. 11, 606825, 11 pages.

[92] Society for Freshwater Science; SFS (2013): What is the benthos? and Who are bethologists and what do they do?. North American Benthological Society, Retrieved 4/11/2020, from: http://98.129.104.33/AboutSFS/What-is-the-Benthos-.aspx

[93] Tagliapietra D. and Sigovini M. (2010). Benthic fauna: collection and identification of microbenthic invertebrates. NEAR curriculum in natural environmental science. 88, 253-261.

[94] Teixeira, H.L.G. (2010): Benthic macroinvertebrates as ecological indicators for Estuarine and coastal ecosystems: Assessment and intercalibration. PhD. dissertation in Biology (Scientific area of Ecology), University of

[95] Thompson, L.R., Sanders, J.G., McDonald, D., Amir, A., Ladau, J., Locey, K.J., Prill, R.J., Tripathi, A., Gibbons, S.M., Ackermann, G., Navas-Molina, J.A., Janssen, S., Kopylova, E., Vázquez-Baeza, Y., González, A., Morton, J.T., Mirarab, S., Zech, X.Z, Jiang, L., Haroon, M.F., Kanbar, J., Zhu, Q., Jin S.S., Kosciolek, T., Bokulich, N.A., Lefler, J., Brislawn, C.J., Humphrey, G., Owens, S.M., Hampton-Marcell, J., Berg-Lyons, D., McKenzie, V., Fierer, N., Fuhrman, J.A., Clauset, A., Stevens, R.L., Shade, A., Pollard, K.S., Goodwin, K.D., Jansson, J.K., Gilbert, J.A., Knight, R., Earth Microbiome Project Consortium (2017): A communal catalogue reveals Earth's multiscale microbial diversity. Nature, 551 (7681), 457-63. 
[96] Venter, O., Pillay, D., Prayag, K. (2020): Water filtration by burrowing sand-prawns provides novel insights on endobenthic engineering and solutions for eutrophication. Sci. Rep., 10, 1913 (2020), 11 pages. https://doi.org/10. 1038/s41598-020-58677-1

[97] Wen, X., Chen, F., Lin, Y., Zhu, H., Yuan, F., Kuang, D., Jia, Z., Yuan, Z. (2020): Microb ial indicators and their use for monitoring drinking water quality: A review. Sustainability, 12, 2249, 14 pages.

[98] Wikipedia (2020): Benthos. Retrieved on 27/5/2020, from: https://en.wikipedia. org/wiki/ Benthos

[99] Woehle, C., Roy, A.-S., Glock, N., Wein, T., Weissenbach, J., Rosenstiel, P., Hiebenthal, C., Michels, J., Schönfeld, J., Dagan, T. (2018): A novel eukaryotic denitrification pathway in Foraminifera. Curr. Biol. (CB), 28 (16), 2536-43.

[100] Worden, A.Z., Not, F. (2008): Ecology and diversity of picoeukaryotes. In: Microbial Ecology of the Ocean, Edited by Kirchman D.L., $2^{\text {nd }}$ edn. New York: Wiley-Liss, 159-96.

[101] Xue, Y., Chen, H., Yang, J.R., Liu, M., Huang, B., Yang, J. (2018): Distinct patterns and processes of abundant and rare eukaryotic plankton commu-nities following a reservoir cyanobacterial bloom. ISME J., 12, 2263-77.

[102] Zaleha, K., Farah Diyana, M.F., Amira Suhaili, R., Amirudin, A. (2009): Benthic community of the Sungai Pulai seagrass bed, Malaysia. Malays. J. Sci., 28(2),

[103] Zeppilli, D., Leduc, D., Fontanier, C., Fontaneto, D., Fuchs, S., Gooday, A.J., Goineau, A., Ingels, J., Ivanenko, V.N., Kristensen, R.M., Neves, R.C., Sanchez, N., Sandulli, R., Sarrazin, J., Sørensen, M.V., Tasiemski , A., Vanreusel, A., Autret, M., Bourdonnay, L., Claireaux, M., Coquillé, V., De Wever, D., Rachel, D., Marchant, J., Toomey, L., Fontanier, C. (2018): Characteristics of meiofauna in extreme marine ecosystems: a review. Mar. Biodiv., 48, 35-71.

[104] Zhang, H., Sekar, R., Visserg, P.M. (2020): Editorial: Microbial ecology in reservoirs and lakes. Lausanne: Frontiers Media SA, Front. Microbiol., 11(1348), 5-8.

Citation: SAMAH SULAIMAN, et.al., "Environmental Genomics and Biodiversity of Macro- and Microbenthic Communities in the Red Sea Coast of Jeddah City", International Journal of Research in Environmental Science (IJRES), vol. 7, no. 1, pp. 38-53, 2021. Available: DOI: http://dx.doi.org/ 10.20431 /2454-9444.0701005

Copyright: (C) 2021 Authors. This is an open-access article distributed under the terms of the Creative Commons Attribution License, which permits unrestricted use, distribution, and reproduction in any medium, provided the original author and source are credited. 